\title{
General Behavior and Indebtedness of Tocantins-Brazil between 2000 and 2018
}

\section{Carlos Vicente Berner ${ }^{1 *}$, Andre Luiz Marques Serrano², Barbara Dias Fernandas $^{3}$}

${ }^{1}$ University of Brasilia, Brazil \& Federal University of Tocantins, Brazil.

${ }^{2}$ University of Brasilia, Brazil.

${ }^{3}$ Federal University of Tocantins, Brazil.

\section{*Corresponding Author: Carlos Vicente Berner}

\begin{abstract}
The aim of this study is to analyze the general behavior and indebtedness of Tocantins State in Brazil, between the years 2000 and 2018. In order to reach the results, short-and long-term indicators of debt, as well as the behavior of the indebtedness are estimated. Data were collected from government account, extracted from the sites of the Audit Office of National Treasury Secretary and from the Estate Secretary of Tocantins. This paper is grounded on Agency Theory applied to public sector, and on descriptive statistics techniques by means of dispersion measures. Results show trends in behavior of public indebtedness in Tocantins. The first and second ones reveal tendency to decrease in the second half of the year, and to increase in the first half of the year, depicting a larger debt than the State paying capacity. The second and third trends, although distinct indicators, converge due to the increase of the debt indicators between 2014 and 2015
\end{abstract}

Keywords: Indebtedness, Indicators, Public Account, Tax Liability Law, Tocantins.

$\begin{array}{lll}\text { Article Received: } 30 \text { July } 2020 & \text { Revised: } 19 \text { August } 2020 & \text { Accepted: } 26 \text { August } 2020\end{array}$

\section{Introduction}

Public indebtedness impacts the economic growth or the economic recession of federated entities to affect directly the country's economy [1]. The first impact is in the acting of state funding, making investments and minimizing of exchange rate stagnation. A second influence is in the economic control over the form of fiscal, exchange and monetary policies. Public indebtedness, while administered, corresponds to an important value which allows to expand the population well-being.

In addition, it corroborates for a good function of the national economy, that is, the public indebtedness as sustainable situation can meet emergency expanses and secure sudden funding of government projects with mediumand long-term return [2]. In Brazil, public debt, mainly in Colonial times and beginning of Imperial period, was not constituted as a sustainable situation. The increase in domestic debt resulted in the emergency of external public debt in Imperial period, totalizing fifteen loans in order to mitigate the crisis situation in Colonial times. Thus, domestic and foreign loans corroborated for the budget deficit of more than 758.182,00 contos de réis (the Brazilian currency at that time), arising from a collected revenue and from a committed expense of $3.738 .383,00$ contos de réis. In the Brazilian states, the public debt aroused during the 60's, caused by the lack of control in loan acquisition.

Thereby the Federal Government, as a contention measure, instituted the Act No. 9.496, from September 11 th, 1997 [3], establishing criteria for the consolidation, the assumption and refinancing by the Union of the public security debt, besides other responsibilities of the States and Federal District. The state of Tocantins was one of the two states which did not take part in that renegotiation of the public state debt with the Union. This is due to the Act. No. 8.727, from November $5^{\text {th }}$, 1993 [4], prior to Act No. 9.496/97 [3], establishing the guidelines for 
consolidation and rescheduling by the Union of the domestic debt, directly and indirectly, of the States of Federal District and Counties.

The Act 8.727/93 [4] allowed Tocantins to renegotiate approximately $69 \%$ of the total domestic debt representing monetarily $\mathrm{R} \$ 68$ million, of a total contracted domestic debt of $\mathrm{R} \$ 98$ million [5]. That said, this study attempts to answer the following: What is the behavior of Tocantins state, in the period between 2000 and 2018? Thus, as a general aim: analyzing the behavior of the public indebtedness of Tocantins in the respective period.

Specifically, we seek to: (1) calculate the indicators of the short-and-long-term debt of Tocantins State; and (2) verify the behavior of Tocantins indebtedness. This paper is theoretically anchored in Agency Theory applied to public sector (asymmetry of information), and in the performance of public entities. As methodological contribution, descriptive techniques are applied through dispersion measures (average, median, standard deviation and range and variation coefficient). The relevance of this study is justified for revealing to society the diagnosis of the public debt, providing relevant information to the administration of public resources by the federated entity, over the sample period.

Furthermore, the citizens are the ones who suffer the impacts of governors' and people in charge of expenditures' decisions, besides being the biggest funders of domestic public debt through investments of Direct Treasury, Investment Funds and Pension Fund. Even the statistics proving that most part of investor shareholders of Federal Public Debt are finance corporations, with $44.01 \%$ (value referring to the sum of holdings by title of the finance corporations and private pension relative to the month of April, 2019.

\section{Recovered}

from:

https://www.tesouro.fazenda.gov.br/relatoriomensal-da-divida), the capital employed by finance corporations, in this investment, is from account holders, even if they do not receive the appropriate remuneration for the operation. The first part of this paper discusses about the theories on public debt nationally and statewide. Next, the methodological procedures, results and analysis are shown. And finally, the conclusions.

\section{Theoretical Framework}

\section{Public Debt in Colonial, Imperial and Republican periods}

In Brazil, the history of domestic public debt comprises three periods: Colonial (1500-1822) -mainly marked by the establishment of the first Banco do Brasil (Bank of Brazil) in 1808; Imperial (1822-1889)-marked by the creation of the Law of November 15 $15^{\text {th }}, 1827$; and Republican (1889-1963) - period when the first prime Minister of Finance instituted the issue of bearer bonds [2]. In Colonial times (Sixteenth to Seventeenth centuries), the domestic government debt, as a management tool, was still unexplored and it was just confined to some governors' loan operations.

As soon as the Colony's situation was determined, 1761 to 1780 , at the behest of Luiz de Vasconcelos e Souza (viceroy of the colonial Brazil), an annual deficit greater than 100 contos (Brazilian currency in Colonial period) and the public debt was up to 1,200 contos. Those debts were only paid off in 1799, when D. João VI, in order to ease the economic crisis, ordered its payment in policies with embedded interest of $5 \%$.

According to Bouças [6], even with all the measures taken in Colonial period, the debt picture has not changed so much, since D. João VI, on returning to Lisbon, takes with him good part of the treasure (gold and silver coins) of the country, nothing left to the Brazilian coffers.

Considering this fact, D. Pedro I, in 1821, takes over Brazil as regent prince, with the country in an instable economic situation, setting up the bottom line in public debt in the Imperial Brazil. One of the greatest marks of the period, which served as a basis for the creation of Central Bank, was the law of November 15 $15^{\text {th }}, 1827$ [7], known as the "cornerstone of public credit in Brazil". Arranged in 75 articles, the law has undergone a few changes over the 140 years which preceded the creation of Central Bank and, therefore, originated the domestic debt founded in Imperial Brazil [8].

The law deals with recognition and legislation of public debt, foundation of the domestic debt and establishment of the Amortization Fund. 
Instituted by Constitutional Emperor, this law has four titles, namely: (1) recognition of the public debt; (2) legislation of public debt; (3) foundation of domestic debt; and (4) Amortization Fund. The first title deals with the recognition of the public debt and it consists of a single chapter and two articles which define public debt as debts of any nature, origin or class originated from authentic and legal contracted by the Government - either in the Emperor or out of it, covered until the end of the year 1826, with the exception of debts prescribed via the license of May $9^{\text {th }}, 1810$.

The second title which deals with the legislation of public debt is divided into two chapters (the big book of Brazil's debt and the registrations of the big book and its subsidiaries). The first nominated as the "big book of Brazil's debt" deals mainly with what is in the book of Brazil's debt and in its subsidiary books and; the second chapter deals with when it should be registered and what should be registered in the big book and its subsidiaries. The recognition of the domestic debt in Brazil emerged through the Law of November $15^{\text {th }}, 1827$ [7]. which established the issue of 12 thousand contos de réis, defined in its title $3^{\text {rd }}$, article 19 .

This value was put into circulation through policies of funds of more than 400 contos de réis, applying the policies of this capital in purchase or change of 6 thousand contos de reis, in the payment of public creditors and in the supply of deficit of National Treasure for the year 1828. Lion (Federal Income Tax) [9] shows the impact of domestic public debt in the public budget and subdivide the process in four subperiods -from 1828 to 1840; from 1841 to 1860; from 1861 to 1880 and from 1881 to 1889 , as it is presented in Table 1 below.

Table 1: Evolution of domestic debt founded in the Empire (Values in contos de réis)

\begin{tabular}{|c|c|c|c|}
\hline Period & Issue & Redemption & Balance \\
\hline 1827 & 12,000 & - & 12,000 \\
\hline $1828-1840$ & 25,500 & 3,800 & 31,700 \\
\hline $1841-1860$ & 32,000 & - & 63,700 \\
\hline $1861-1880$ & 340,000 & - & 403,700 \\
\hline $1881-1889$ & 46,000 & 11,300 & 435,500 \\
\hline
\end{tabular}

Source: Lion [9].

There is an increase in public debt between 1860 and 1880, overtaking more than six times the balance of the debt founded in the previous period (from 1841 to 1860), besides long periods of suspended redemption of the debt (1841 to 1880), due to the critical financial situation of the Emperor. The Imperial Brazil finished with a high domestic debt, reaching 435,500 contos de réis. As to the foreign debt, the Imperial Brazil borrowed a total of 46,889,500 pounds, plus interests and amortization rate resulting from these fixed operations, within a total term of up to thirty-eight years, to extinguish debt and interests. Among these fifteen loans, Fig. 1 quantifies a percentage, their significance in relation to a total nominal of the loans contracted by period.

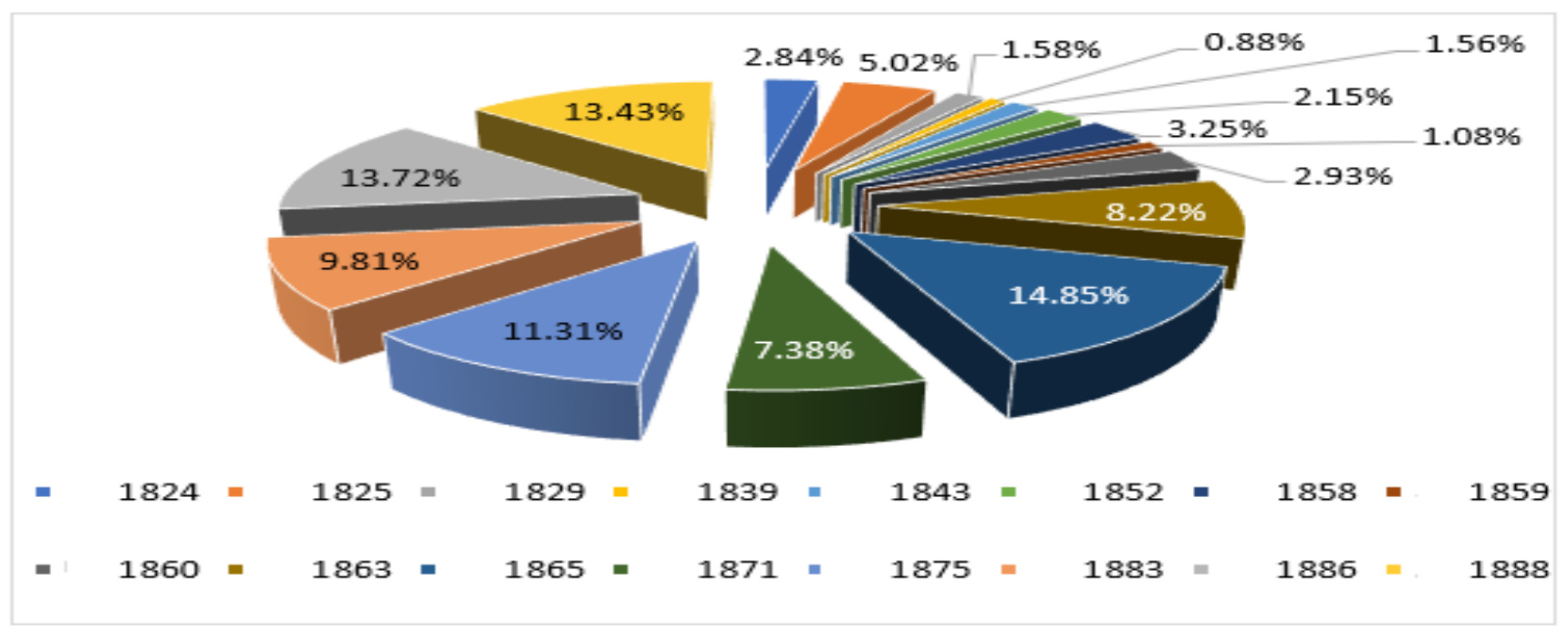

Figure 1: Significance of the loans contracted in Imperial Brazil

Source: adapted from Silva ET. al. [2] 
Among the loans, the ones of more percentage significance were contracted in 1865,1886 and 1888, respectively. All of them occurred in the second foreign debt cycle - understood in the mid-1960s and 1994, characterized, according to Abreu [10], by a long indebtedness cycle, moratoria, temporary renegotiations and permanent agreements. At the end of Imperial Brazil, the country had several loans with a long list of loans redeemed, reaching, according to Bouças [6], a total value of $£ 37,458,000$, in contos de réis, for Carreira [11], culminated in a budget gap of 758,182 contos de réis, resulting from an achieved revenue of $3,738,383$ contos de réis and a budget expenditure of 4,496,565 contos de réis.

According to Pastore [12], from 1889 to 1963, a period of seventy-four years of the Republican Brazil, there were relevant transformation in Brazil public debt, with characteristics which allow understanding the profile of the debt in current days, still marked by the complexity of financings and the restructuring of the public machinery. Apparently, Brazil enjoyed an alleged stability under institutional aspects in the face of assistance secured by the Cash Management. From 1964, with the expansion of the foreign and domestic public debt, besides the increase of stock, there was also an increase of these debt structures, fundamentally, for the advance of the public indebtedness $[6,2,12]$.

After Military Coup, the government instituted Plano de Desenvolvimento Econômico (PAEG) (a Brazilian Economic Development Plan), aiming at continuing the process of economic development and regulating the inflationary process. The government made some fiscal and monetary changes, out of PAEG, in order to cover public debt through the issue of Readjustable National Treasury Bonds (Obrigações Reajustáveis do Tesouro Nacional - ORTN), in order to create the monetary correction, to moderate the rising inflation and to shield investors from negative investments [13].

Despite macroeconomic aspects being connected with the behavior of domestic and foreign debits, it is noted that, in view of the successful events, the debts reach experiences, dynamics and events, stimulated by itself.
A fact that exemplifies these events are the origins of the debt crisis in the early 1980s, which are concentrated on external factors, as well as the rise in the stock of domestic debt, which is delayed until the second half of the 1990s. [14]. In view of the above, concerning Colonial, Imperial and Republican periods, the public debt of the Brazilian states is discussed below, as well as the reality of the state of Tocantins.

\section{State Public Debt}

Abreu [10] highlighted that municipal and state external debt were not added to the list of credit operations during Imperial period. However, before entering the Republican period, the state public debt existed even if not significant. This insignificance of the state public debt was due to the defined legal ceiling for nominal interest rates, established by Decree No. 22626, of April 7th, 1933 [15], which provides for interest in the contracts [16].

The Normative Resolution No. 63/1967 [17] and the law No. 4131/1962 [18] regulated the access to foreign resources in Brazil and, consequently, afforded the rise of an indebtedness economy which provided the insertion in the public section, setting up the second aspect defined by Almeida [16]. In the 1980s, according to Rangel [19] and Almeida [16], there was a concern about how to regulate the rollover of previously accumulated debt stock, in addition to the regulation of new credit operations by states and municipalities.

To address this impasse, in 1987, according to Law No. 7614/1987 [22], the contracting of domestic credit operations with Banco do Brasil was authorized in extraordinary situation under National Treasury responsibility, which authorized the issuance of debt securities as a means to meet the rollover of domestic debt.

The 1990s, mainly due to the adoption of the Plano Real (Real Plan), were marked by considerable growth in the state's liabilities. Rigolon and Giambiagi [20] highlight the $5.8 \%$ increase in net debt of States and Municipalities in relation to GDP in 1989; and by $14.4 \%$ in 1998 . There was an increase in the debt composition, mainly in 1989 , with $39 \%$. 
Although, in the period 1989 and 1998, the debt is equalized at $15 \%$, compared to GDP.

It is observed that the debts are inherent to the liabilities renegotiated in the period. In 1997, due to the increase in interest rates to maintain inflationary control at the beginning of the Real Plan, the Federal Government renegotiated the state debt, based on Law No. 9496, of September 1997 [23]. The Union had already tried to renegotiate the debt of the States and the Federal District, in 1989, through Law No. 7976 / 89 and, in 1993, through Law No. 8727 / 93, but these attempts failed to contain the level of indebtedness [21].

The 1997 renegotiation, through Law No. 9,496 / 97 [23], resulted, according to Pellegrini [21], in a contract signed between the Brazilian States and the Union, with the exception of the states of Tocantins and Amapá, which included the state liabilities that were excluded in the 1989 and 1993 renegotiations. In this way, the Union started to assume all the liabilities of these states and the states assumed the obligation towards the Union; in addition to state liabilities, the federal government also assumed the state securities debt, constituted up to March 31 ${ }^{\text {st }}$, 1996, as a result of interest rates on the state debt and its effects on it. Complementary Law No. 156, of December $28^{\text {th }}, 2016$ [24] establishes the Aid Plan for States and the Federal District and measures to encourage fiscal rebalancing. It amends Complementary Law No. 148, of November 25, 2014 [25]; Law No. 9496, from September 11th, 1997 [23]; Provisional Measure No. 2192-70, of August 24th, 2001 [24]; Law No. 8727, of November 5th, 1993 [26]; and Complementary Law No. 101, of May 4th, 2000 [27].

In addition, it amended the wording to Article 2 of Law No. 9496 / 1997 [23], which deals with the goals or commitments of the Restructuring and Tax Adjustment Program. The contract between the states and the Federal District and the Union, on September 1997, was signed to be paid in 360 (three hundred and sixty) monthly installments, calculated monthly, based on the Price Table, subject to interest, calculated at the minimum rate $6 \%$ per year, and monetary restatement, based on the variation of the General Price Index-Internal Availability (IGP-DI), established by Fundação Getúlio Vargas
(FGV). This 1997 renegotiation included $77.9 \%$ of the net debt of States and Municipalities, which represented $11.3 \%$ of the Gross Domestic Product [20].

Among the largest debts that were renegotiated, Mora [28] informs that they were from the richest states in the Federation, such as Rio de Janeiro, São Paulo, Minas Gerais and Rio Grande do Sul and these states represented $90 \%$ of the debt renegotiated in 1997. Complementary Law No. 101, of May 42000 (known as the Fiscal Responsibility Law) [27] is the Federal Law regulated by article 165 , paragraph 9 , of the 1988 Constitution of the Federative Republic of Brazil [29], which establishes public finance rules aimed at responsibility in fiscal management, laid down in ten chapters that deal with preliminary provisions, planning, public revenue, expenditure, voluntary transfers, the allocation of public resources to the private sector, debt and indebtedness, asset management, transparency, control and inspection and final and transitory provisions.

In the context of Brazilian public debt, the Fiscal Responsibility Law established several rules that impacted public debt management at all levels of government. These rules, set out in Chapter VII, of Complementary Law No. 101/2000 [27], include the establishment of basic concepts, the establishment of limits for indebtedness and credit operations, in addition to the creation of rules for the readmission of debt to indebtedness limits [2].

Chapter VII, of Complementary Law No. $101 / 2000$ [27], determines the provisions of debt and indebtedness, presenting six sections, namely: basic definitions, the limits of public debt and credit operations, the debt renewal to limits, credit operations, guarantee and counter-guarantee and the remainder to be paid.

The first section presents the basic definitions related to public debt, such as: consolidated and founded public debt, public securities debt, credit operation, guarantee concession and refinancing of securities debt. The second section determines the limits on public debt and credit operations. The global limits of the consolidated debt of the Union, the States of the Federal District and the Municipalities were submitted to the Federal Senate, complying with the provisions of items VI, VII, VIII and IX, of article 52, of the 
Constitution of the Federative Republic of Brazil of 1988 [29], which was pending regulation before the Fiscal Responsibility Law. The renewal of the debt to the limits, contained in section III, of chapter VIII of the law, deals with the procedure of the Federation entity when it exceeds the limit of the consolidated debt of a four-month period.

Article 31 limits up to three quarters subsequent to the period in which the consolidated debt was exceeded for the federative entity to fall into again, being obliged to reduce by at least $25 \%$, in the first quarter, after the excess of the debt. The fourth section of Chapter VIII of the Federal Responsibility Law (On Credit Operations) is divided into six subsections that deal with contracting, prohibition, credit operations in anticipation of budget revenue, operations with the Central Bank of Brazil, guarantee and counter guarantee and the remainder to be paid.

\section{State of Tocantins}

Tocantins was one of the two states which was excluded from the contract signed between the states, the Federal District and Union, through Law No. 9496, from September 22nd, 1997 [3], focusing on debt refinancing. From the legal point of view, the states of Amapá and Tocantins, in addition to the 5,384 municipalities that have not signed contracts with the Union, are not bound by the provisions of Law No. 9496, 1997, or even Provisional Measure No. 2185-35, 2001 [5].

For Tocantins this renegotiation was advantageous, since a large part of the founded debt was renegotiated, totaling $\mathrm{R} \$ 68$ million renegotiated, out of a total internal contractual debt of $\mathrm{R} \$ 98$ million, that is, this pact resulted in a renegotiation of more than $69 \%$ of Tocantins' total domestic debt.

In 1995, the credit line, implemented by the National Monetary Council Votes 162/95 and $175 / 95$, intended to make sustainable fiscal adjustment feasible for Brazilian states. To this end, it was intended to finance the settlement of overdue debts, in addition to transforming debts by anticipating revenue into founded debt. The composition of the indebtedness of the state of Tocantins started from the analysis of short and long-term debt indicators.
Freire and Freire Filho [30] Define the shortterm debt indicator as an index that seeks to reflect the degree of indebtedness of the main debt, which makes it possible to identify the compliance and non-compliance with the budgetary-financial balance during the financial year. The long-term debt indicator emerged as a way to facilitate the calculation of the consolidated net debt, contained in Federal Senate Resolution No. 40/2001 [31], and can be used as a parameter for monitoring subnational debt. This indicator makes it possible to verify how much of the current annual revenue is not compromised with long-term debt.

\section{Methodology}

With the aim of analyzing the behavior of public indebtedness in the State of Tocantins, between 2010 and 2018, this study employed quantitative and qualitative approaches, in view of the statistical techniques used, as well as the reflection on them. Descriptive statistics techniques were used, using dispersion measures (mean, median, standard deviation, amplitude and coefficient of variation). According to Martins [32], dispersion measures are static values that make it possible, from an average, to assess the degree of variability or dispersion of the values.

Another measure of dispersion used in this study was that of amplitude, which consists of the difference between the minimum value of the observation and the maximum value. Thus, from the data collected, these components of descriptive statistics were used to verify how the elements are distanced. In line with the descriptive statistical technique, the content analysis technique was used, aiming to expand explanations, descriptions and hypotheses to the subjective scope that make it possible to understand the described statistical results [33].

\section{Results and Discussion}

After data collection, they were tabulated to facilitate the verification of their interrelationships. The tabulation was made respecting the variables that make up the two debt indices. For the short-term debt rate, the variables remaining payable and current revenue collected were used; nevertheless, the long-term debt rate was tabulated in order to show the variables total liabilities, financial 
liabilities and available assets (cash and cash equivalents). Through these variables, two other variables were necessary for the longterm indicators: the share of unpaid liabilities in the financial liability as a percentage and the evolution of the debt, in addition to the use of a variable used in both indicators: the current revenue collected.

\section{Short-term Debt Rate}

For the analysis of the results, the higher the index, the greater the degree of indebtedness of the entity, that is, the remains to be paid (the obligations) are in the numerator; the revenue (credit available for payment) is in the denominator, as represented by the following formula:

$$
S T D=\frac{\text { Remains to pay }}{\text { Current Revenue Collected }}
$$

In the state of Tocantins, for the calculation and analysis, tabulation of the monitoring of the liabilities to be paid was made through monthly state reports, and the monitoring of the current revenue was carried out

\section{Remains to Pay}

The following formulas exemplify how the unpaid and unprocessed remains are found within the state.

$$
\begin{aligned}
\text { RTP } & =\text { Committed Expenses }- \text { Paid Expenses } \\
\text { RUP } & =\text { Paid Expenses }- \text { Paid off Expenses }
\end{aligned}
$$

For the analysis of the payable remains, Information from 2008 to 2017 was used, as monthly shown in Fig. 2.

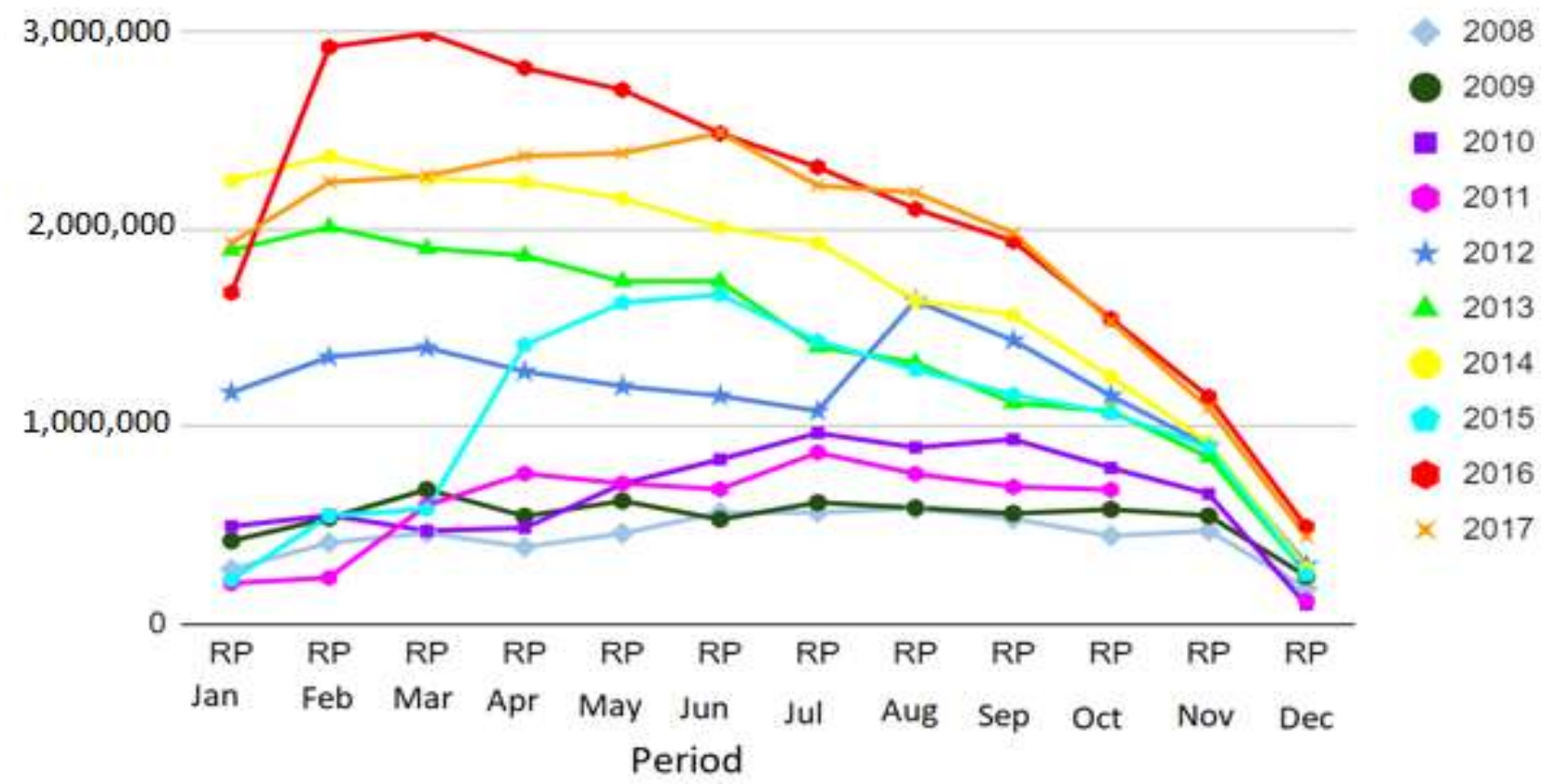

Figure 2: Execution of Payable Remains (2008 to 2017)

It is possible to identify the trend of reducing the amount of liabilities to be paid in December. This is a normal trend, given that the remainder to be paid is committed expenses, not paid until December $31^{\text {st }}$ of the same year, valid until December $31^{\text {st }}$ of the following year. This practice allows States to curb the rollover of debts for the next term, so the smaller the debt, the better it is for the State, as it indicates that it is complying with what was determined by the budget in the current year.

Therefore, this reduction, in December, characterizes the fulfillment of obligations towards third parties. As for 2011, in the month of November, none of the monthly reports were published by the state. Regarding the unavailability of the data to be paid, between 2000 and 2008, it was found, 
through dialogues with the General Accounting Superintendent, that the State of Tocantins changed the accounting system and the information was not exported to the new system, justifying the reduction of the sample of the remains to be paid for this study.

\section{Current Revenue Collected}

The current revenue collected represents the amount originated from the collection of tax revenues, contributions, equity, services, current transfers and other current revenues. It is a report instituted by the Fiscal Responsibility Law, in compliance with paragraph 3, article 165, of the Federal Constitution, through its item I, article 53.
This device requires, in the composition of the summary report, the determination of the current net revenue, in order to evidence its evolution, as well as the performance forecast until the end of the year. This report must be published within thirty days, after the end of each two-month period, a report that has been made available by the State of Tocantins since 2000, the year in which the LRF came into force.

These reports make up the financial statements as an integral and fundamental part to measure the performance of the state tax collection. According to this information contained in the Summary Reports on Budgetary Execution of the Fiscal Responsibility Law, the revenue behavior follows the following pattern:

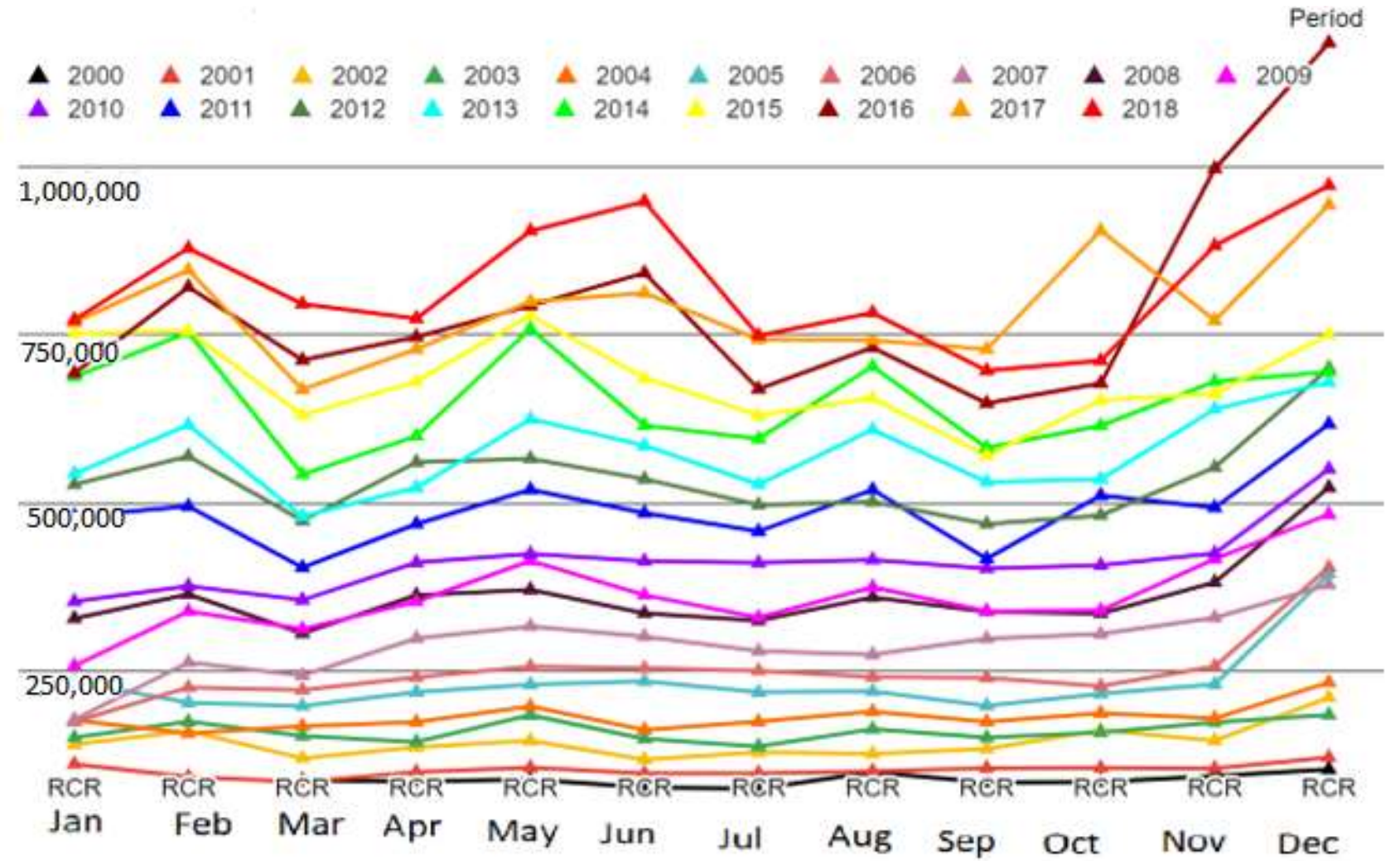

Figure 3: Collection behavior of the state of Tocantins (2000 to 2018)
A greater collection is identified in December, for the period from 2000 to 2018, with the exception of the years 2014 and 2015. In these two years, the month with the highest revenue was May. This is justified by the tendency of growth in the collection of IPVA (it is a Brazilian tax on vehicle ownership), in the months of May and June, and by the increase in revenue of an equity nature. Another explanation for this reduction is the economic recession that Brazil suffered in 2014, which, according to reports by the Getúlio Vargas Foundation (FGV), was felt for at least four quarters and the revenue behavior also followed a defective pattern in this period. Another assessment is regarding the collection of the year 2000. As a result of Complementary Law No. 101, of May 4, 2000 [27], the collection for the months of January and February was not disclosed. This is because, in its article 2 , item IV, $\S 3$, of the Fiscal Responsibility Law [25], it requires the calculation of the current net revenue from the sum of the revenues collected in the month in reference and in the previous eleven. 
The first collection report, available from the State of Tocantins, refers to the rendering of accounts for the first two months of 2001 - the year after the LRF came into force. In this report, it is possible to extract the behavior of the collection of February and the eleven months that preceded it, that is, it is possible to follow the behavior of the collection from March 2000 to February 2001. Through the dispersion measure (mean, median, standard deviation, amplitude and coefficient of variation), for the current revenue collected, the following behavior is identified during the sampling period:

Table 2: Dispersion measures of current monthly revenues

\begin{tabular}{|c|c|c|c|c|c|c|c|c|c|c|c|c|}
\hline Period & $\begin{array}{c}\text { RCR } \\
\text { JAN }\end{array}$ & $\begin{array}{c}\text { RCR } \\
\text { FEB }\end{array}$ & $\begin{array}{c}\text { RCR } \\
\text { MAR }\end{array}$ & $\begin{array}{c}\text { RCR } \\
\text { APR }\end{array}$ & $\begin{array}{c}\text { RCR } \\
\text { MAY }\end{array}$ & $\begin{array}{c}\text { RCR } \\
\text { JUN }\end{array}$ & $\begin{array}{c}\text { RCR } \\
\text { JUL }\end{array}$ & $\begin{array}{c}\text { RCR } \\
\text { AUG }\end{array}$ & $\begin{array}{c}\text { RCR } \\
\text { SEP }\end{array}$ & $\begin{array}{c}\text { RCR } \\
\text { OCT }\end{array}$ & $\begin{array}{c}\text { RCR } \\
\text { NOV }\end{array}$ & $\begin{array}{c}\text { RCR } \\
\text { DEC }\end{array}$ \\
\hline Means & 407,198 & 449,420 & 366,180 & 400,354 & 446,230 & 421,801 & 384,045 & 411,005 & 374,062 & 400,918 & 442,932 & 532,983 \\
\hline Median & 340,742 & 370,239 & 312,390 & 362,577 & 413,649 & 362,881 & 329,743 & 374,587 & 339,030 & 339,917 & 416,516 & 522,699 \\
\hline o & 245,657 & 271,221 & 218,603 & 226,710 & 260,070 & 263,019 & 216,367 & 232,991 & 202,004 & 229,588 & 265,589 & 292,194 \\
\hline VC & $60.33 \%$ & $60.35 \%$ & $59.70 \%$ & $56.63 \%$ & $58.28 \%$ & $62.36 \%$ & $56.34 \%$ & $56.69 \%$ & $54.00 \%$ & $57.27 \%$ & $59.96 \%$ & $54.82 \%$ \\
\hline $\begin{array}{c}\text { Minimu } \\
\text { m }\end{array}$ & 111,703 & 92,874 & 85,040 & 86,063 & 88,912 & 76,796 & 75,200 & 99,822 & 84,181 & 85,160 & 94,135 & 103,946 \\
\hline $\begin{array}{c}\text { Maximu } \\
\text { m }\end{array}$ & 772,083 & 878,210 & 795,638 & 773,940 & 904,119 & 948,001 & 748,665 & 782,614 & 728,306 & 904,428 & 996,773 & $\begin{array}{c}1,183,96 \\
3\end{array}$ \\
\hline \multicolumn{1}{|c|}{$\begin{array}{c}\text { Amplitu } \\
\text { de }\end{array}$} & 660,380 & 785,336 & 710,598 & 687,877 & 815,207 & 871,205 & 673,465 & 682,792 & 644,125 & 819,268 & 902,638 & $7,080,01$ \\
\hline
\end{tabular}

The data reveal a high dispersion, that is, they are highly heterogeneous, since the variation coefficient between the months is in a position of more than $50 \%$, reaching more than $60 \%$ in June. This variation is related to the relevant growth in revenue between the years.

\section{Indebtedness Rate of the State of Tocantins}

In this study, the short-term debt rate followed two different aspects. The first is on the short-term monthly debt rate and the other is the annual aspect; in the first, a monthly sampling from 2008 to 2017 was used, and in the second, an annual sampling from 1999 to 2018. The results that deal with the monthly short-term debt rate are defined by the following Table:

Table 3: Short-Term Debt Rate

\begin{tabular}{|c|c|c|c|c|c|c|c|c|c|c|c|c|}
\hline $\mathrm{Pe}$ & $\begin{array}{c}\text { STDR } \\
\text { JAN }\end{array}$ & $\begin{array}{c}\text { STDR } \\
\text { FEB }\end{array}$ & $\begin{array}{l}\text { STDR } \\
\text { MAR } \\
\end{array}$ & $\begin{array}{c}\text { STDR } \\
\text { APR }\end{array}$ & $\begin{array}{l}\text { STDR } \\
\text { MAY }\end{array}$ & $\begin{array}{c}\text { STDR } \\
\text { JUN }\end{array}$ & $\begin{array}{c}\text { STDR } \\
\text { JUL }\end{array}$ & $\begin{array}{c}\text { STDR } \\
\text { AUG }\end{array}$ & $\begin{array}{c}\text { STDR } \\
\text { SEP }\end{array}$ & $\begin{array}{c}\text { STDR } \\
\text { OCT }\end{array}$ & $\begin{array}{l}\text { STDR } \\
\text { NOV }\end{array}$ & $\begin{array}{c}\text { T STDR } \\
\text { DEC } \\
\end{array}$ \\
\hline 2008 & 0.8510 & 1.1337 & 1.5105 & 1.0805 & 1.2449 & 1.6858 & 1.7432 & 1.6300 & 1.5777 & 1.3360 & 1.2385 & 0.3465 \\
\hline 2 & & 867 & & 503 & & & & & & & & \\
\hline 2 & & 1658 & & 1883 & & & & & 824 & & 55 & \\
\hline 2 & 20 & 4762 & 4930 & 306 & 33 & & & & 671 & $\underline{0}$ & 0 & 916 \\
\hline 2 & 7 & 786 & 04 & 344 & 12 & 21 & 62 & 701 & 0717 & $.40 \zeta$ & .632 & .4288 \\
\hline 2 & 3 & 685 & 75 & 746 & 28 & 96 & 37 & .1790 & 114 & 0176 & 57 & 818 \\
\hline 201 & 719 & 1484 & 1633 & 7417 & 31 & 2707 & 482 & 354 & 6916 & 0420 & 11 & 058 \\
\hline 2 & 3014 & 7265 & 67 & 0811 & 32 & 371 & 2783 & 87 & 0414 & 6370 & 3561 & .3371 \\
\hline 2 & 267 & 5641 & 2031 & 7756 & 4153 & .9552 & .4630 & 8793 & .9964 & .2862 & 1568 & 4168 \\
\hline 2017 & 5165 & 3482 & 4006 & 2573 & 9885 & 677 & .9935 & .9493 & 7220 & 19 & 4205 & .4701 \\
\hline $\mathrm{M}$ & 3566 & 2.0397 & 6144 & 4164 & 2062 & 448 & 4699 & 14 & .2870 & .84 & 2361 & 0.3665 \\
\hline Medi & 489 & 2.0397 & 6144 & 2844 & 1312 & 448 & 2.3599 & 90 & .2870 & .8416 & .3257 & 3818 \\
\hline & 195 & 1092 & 755 & 7772 & 08 & 6965 & .6008 & 0.6215 & .5620 & .3641 & 4560 & 072 \\
\hline $\mathrm{VC}$ & $.30 \%$ & $54.38 \%$ & $.79 \%$ & $44.58 \%$ & $34.48 \%$ & $.70 \%$ & $24.32 \%$ & $27.73 \%$ & $24.57 \%$ & $19.77 \%$ & $6.89 \%$ & $9.25 \%$ \\
\hline inim & 3014 & 4762 & 9267 & 805 & 49 & 125 & 1.7432 & 1.4 & 1.5777 & 1.3350 & .0000 & 0.1828 \\
\hline N & 4903 & 5641 & 31 & 56 & 53 & 07 & 30 & 01 & 3.0717 & 30 & .6328 & .5041 \\
\hline Amplit & 3.1889 & 3.0879 & 3.2764 & 2.6951 & 2.1703 & 1.8582 & 1.7198 & 1.8021 & 1.4940 & 1.0730 & 1.6328 & 0.3212 \\
\hline
\end{tabular}

As the remains to be paid showed a great reduction in all years and since he is the numerator of the short-term debt indicator, a lower debt is expected due to the increase in revenue. in the month of December in all years. with the exception of 2014 and 2015 . Revenue represents the denominator and lower debt is expected in December. This trend was confirmed in all years, the shortterm debt rate is lower in December.
This confirms that the State of Tocantins is executing its public policies, as planned, so much that the December average adds up to just 0.3665 , being that, in the second semester, there is a more significant decrease in the degree of indebtedness.

In addition, there were very high rates. Especially in the years 2013 and 2014, reaching 4.1633 . This is worrying in relation 
to indebtedness because it reveals that the state spent more than it collected. This finding confirms the data released by the Central Bank in 2013. through indicators from the public accounts of the states, which showed that Tocantins occupied the 3rd position of the 11 states that spent more than collected in 2013 , generating a primary deficit of $2.7 \%$. second only to Pernambuco (3\%) and Rondônia (11\%) (Recovered on January 20, 2020) from https://www.bcb.gov.br/).

\section{Long-Term Debt Rate}

The long-term debt rate is composed of the variables: total liabilities, financial liabilities, available assets (cash and cash equivalents), remains to be paid (processed and unprocessed) and current revenue. Based on this, the variable evolution of debt is calculated, which, divided by the current revenue collected, represents the long-term debt rate.

This indicator, for Freire \& Freire Filho (2006), is the closest to that described in Resolutions No. 40 and 43/2001, as soon as this rate arose due to the difficulty in determining the indebtedness of the States.
For these data, the analysis of the annual accounts was carried out, justified by the lack of information by the government and the lack of mandatory monthly publication by the federated entities.

\section{Evolution of Debt}

In order to calculate the evolution, it is necessary to subtract from the total liability the value referring to the available asset and from this value, the subtraction of the financial liability and the remains to be paid must be removed. The total liability is the sum of the financial liability and the permanent liability and represents the obligations assumed by the bodies and / or entities, which can be found in the Entity Balance Sheet.

The available asset or cash and cash equivalent are availability, credits and achievable values in monetary values [30]. The other subtraction refers to the remains to be paid, also used in the short-term debt rate and the financial liability, which represents the entity's short-term obligations. Through these variables, it is possible to identify the following provisions for the annual debt from 1999 to 2018.

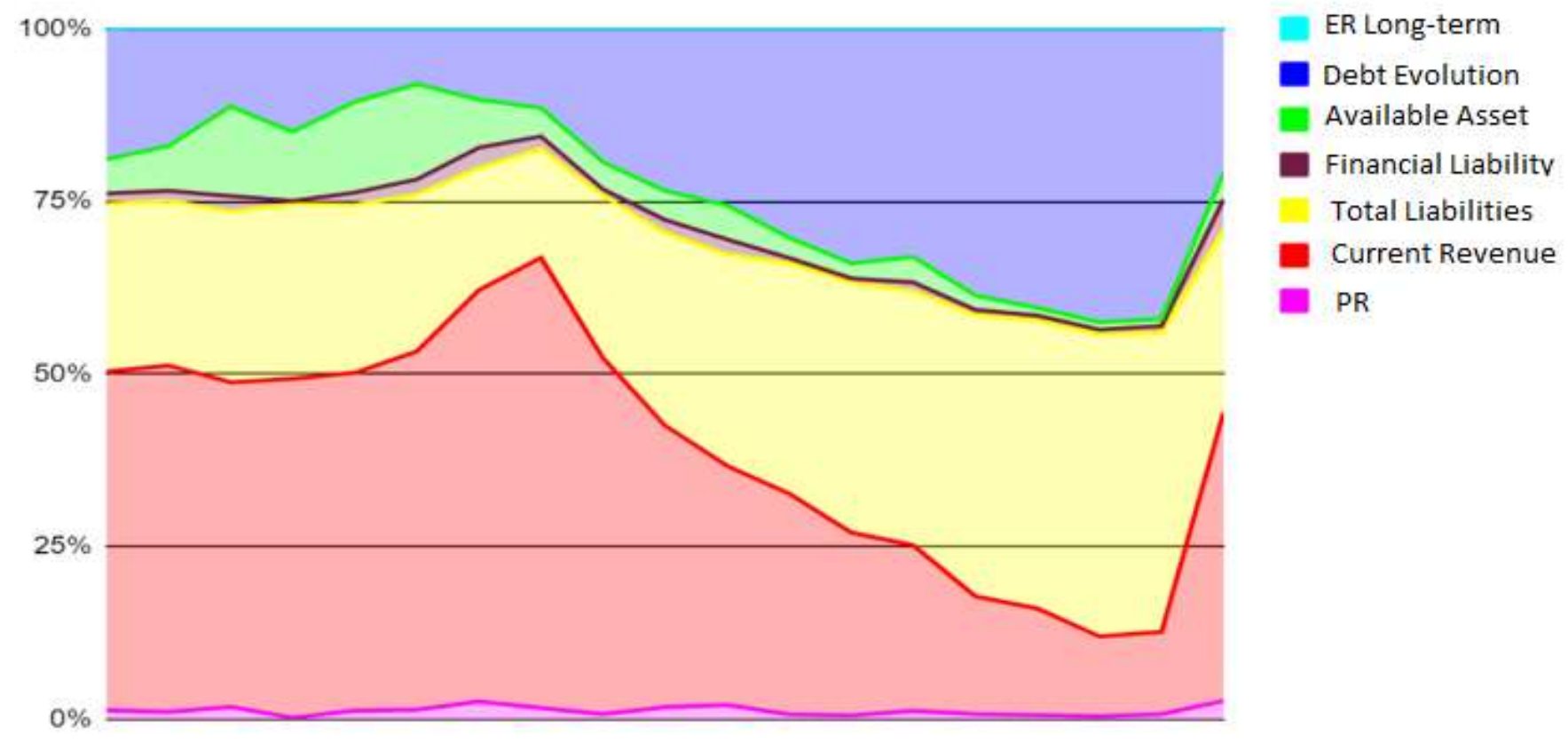

Figure 4: Variables that make up the debt evolution

Fig. 4 represents the totals accumulated over the sample period, and indicates the area that each component occupies at the expense of a period. An increase in tax collection is visible, followed by a decrease compared to total liabilities. This does not mean that there was a reduction in revenue, on the contrary, revenue has been growing over the years, which means that the other components have increased a lot, as in the case of total liabilities. Graph 5 shows the evolution of Tocantins' long-term debt and the 
indebtedness rate, considered as a numerator; the denominator being the same index used in the short-term debt indicator.

DR Long-Term

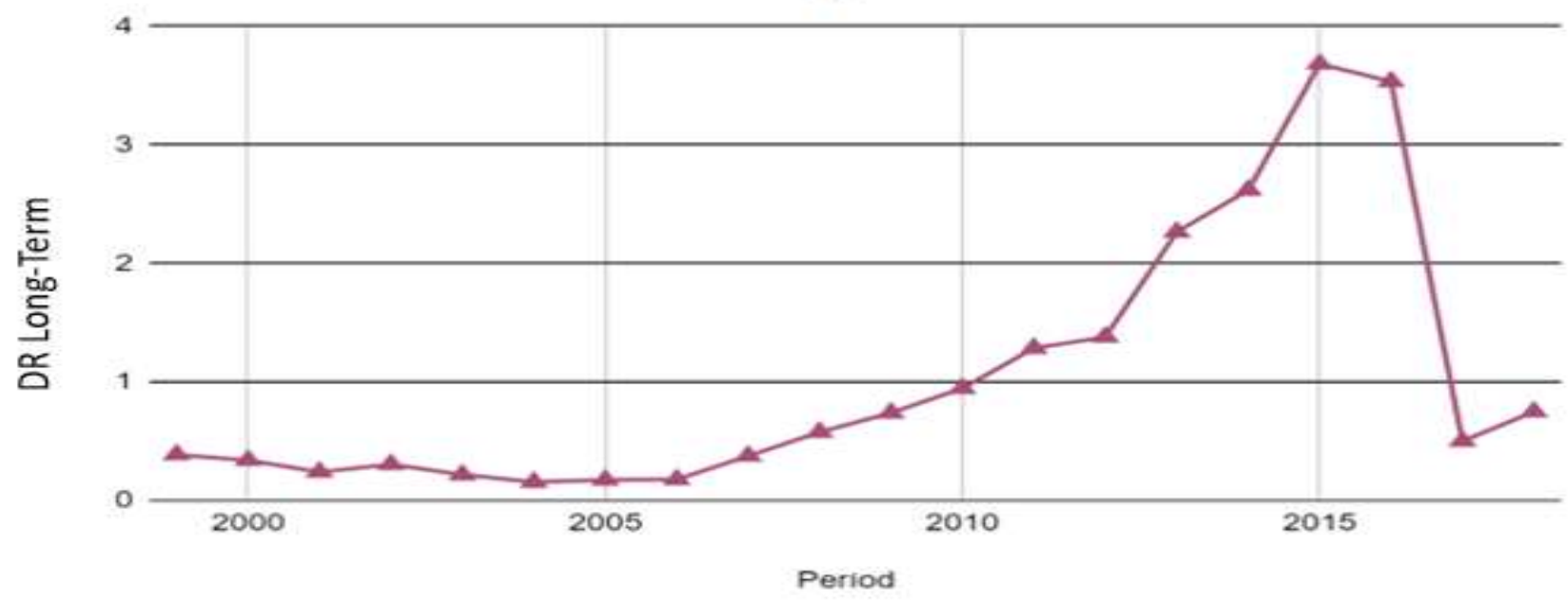

Figure 5: Long-term debt rate

As in the short-term debt rate, it is possible to identify a pattern of growth in the rate in the years 2015 and 2016, which again can be explained by the economic recession in the period, indicating that the entities also suffer from the economic recession.

\section{Conclusion}

The behavior of public debt in the state of Tocantins, based on debt indicators, follows three trends. The first and second trends are based on the short-term indicator, which, whether analyzed monthly, shows a tendency to decrease between the months of the second semester, and a tendency to increase between the months of the first semester, reaching values that represent a debt greater than the state's payment capacity.

The second and third trends, even if with different indicators, converge in relation to the growth of debt indicators in the years 2014 and 2015. This only confirms Zilotto's [1] idea that public debt directly impacts economic growth or the economic recession of federated entities and it is important, as Horta [34] points out, to develop strategies for macroeconomic stabilization for the management and control of public debt.

\section{References}

1. Ziliotto GA (2011) Dois séculos de dívida pública: a historia do endividamento público brasileiro e seus efeitos sobre o crescimento econômico (1822-2004). São Paulo: Editora Unesp.
Furthermore, the importance of the financial statements and the role of the public accountant for generating relevant information for immediate decision-making is highlighted, which, unfortunately, has not become a habit, given the scarcity of this information on the websites of the bodies and entities. The only information available is mandatory information and, as evidenced in the results, not even the government has access to it.

For further studies, it is recommended to compare the short and long-term debt ratios between the states of the same region, or to compare them between the states of the Union in order to identify and characterize the trends within the states and regions, as in the studies by Campos [35] which analyzes the indebtedness of all Brazilian states and Carvalho, Oliveira and Santiago [36] which deals with the indebtedness of all states in the northeast region. Although, these two studies bring these indicators of an annual character, and with a small temporal sample, they compare the indicators of each state and characterize the trends of the region, and / or the state.
2. Silva AC, Carvalho LO, Medeiros OL (Orgs.) (2009) Dívida Pública: a experiência brasileira. Brasília: Secretaria do Tesouro Nacional; Banco Mundial.

3. Lei $\mathrm{n}^{\mathrm{o}} 9.496$, of September $11^{\text {th }}$, (1997) it establishes criteria for the consolidation of the 
assumption and refinancing, by the Union, of public securities debt and others that it specifies the responsibility of the States and the Federal District. Recovered from http://www.planalto.gov.br/ccivil_03/leis/L9496. htm.

4. Lei $\mathrm{n}^{0}$ 8.727, of November $5^{\text {th }}$, (1993) It establishes guidelines for the consolidation and rescheduling, by the Union, of domestic debts of the direct and indirect administrations of the States, the Federal District and the Municipalities, and takes other measures. Recovered from http://www.planalto.gov.br/ccivil_03/LEIS/L872 7.htm.

5. Rocha CAA (2007) Dívidas e Dúvidas: Análise dos Limites Globais de Endividamento de Estados e Municípios [Texto para discussão. $\mathrm{N}^{\circ}$ 34]. Brasília. DF: Consultoria Legislativa do Senado Federal. Recovered from https://www12.senado.leg.br/publicacoes/estudo s-legislativos/tipos-de-estudos/textos-paradiscussao/td-34-dividas-e-duvidas-analise-doslimites-globais-de-endividamento-de-estados-emunicipios.

6. Bouças V (1950) História da dívida externa. 2. ed. Rio de Janeiro: Edições Financeiras S.A.

7. Law of November $15^{\text {th }}, 1827$ (1827) Recognition and legalization of public debt and foundation of domestic debt and establishment of the Amortization Fund. Recovered from https://www2.camara.leg.br/legin/fed/lei_sn/182 4-1899/lei-38438-15-novembro-1827-566772publicacaooriginal-90262-pl.html.

8. Neto AL da S (1980) Dívida pública interna federal: uma análise histórica e institucional do caso brasileiro. Brasília: UnB.

9. Leão AAC (2003) A dívida interna pública [Mimeo].

10. Abreu M de P (1999) Brasil. 1824-1957: bom ou mau pagador? Rio de Janeiro: Pontifícia Universidade Católica - Departamento de Economia (Texto para discussão. n. 403).

11. Carreira L de C (1980) História financeira e orçamentária do Império do Brasil. 2 tomos. Brasília: Senado Federal; Rio de Janeiro: Fundação Casa de Rui Barbosa.

12. Pastore AC (1995) Déficit público, a sustentabilidade do crescimento das dívidas interna e externa. senhoriagem e inflação: uma análise do regime monetário brasileiro. Revista de econometria. 14(2): 177-234. Recovered from http://bibliotecadigital.fgv.br/ojs/index.php/bre/a rticle/view/2972/1868.

13. Palombo PEM (2010 setembro). Fatores determinantes da evolução e sustentabilidade da dívida pública. Anais da Associação Nacional de Pós-Graduação e Pesquisa em Administração.
Rio de Janeiro. RJ. 34. Recovered from http://www.anpad.org.br/diversos/down_zips/53/ apb87.pdf.

14. Brennan G, Buchanan JM (1980) the power to tax: analytical foundations of a fiscal constitution. Cambridge: Cambridge University Press.

15. Decreto $\mathrm{n}^{\mathrm{o}} 22.626$, from April $7^{\text {th }}$, (1933) It provides for interest on contracts and other measures. Recovered from http://www.planalto.gov.br/ccivil_03/decreto/D22 626.htm.

16. Almeida. A. O. de, (1996) Evolução e crise da dívida pública estadual [Texto para discussão. $\mathrm{N}^{\circ}$ 448]. Rio de Janeiro. RJ: IPEA.

17. Banco Central do Brasil (1967) Resolução n 63. de 21 de ago. de. Recovered on July 24th, 2019, at

https://www.bcb.gov.br/pre/normativos/busca/do wnloadNormativo.asp?arquivo=/Lists/Normativo s/Attachments/39996/Res_0063_v1_O.pdf .

18. Lei $\mathrm{n}^{\circ}$ 4.131, of September $3^{\text {rd }}$, (1962) it disciplines the application of foreign capital and remittances of money abroad and takes other measures. Recovered from http://www.planalto.gov.br/ccivil_03/leis/L4131.h tm.

19. Rangel MA (2003) Resgates financeiros. restrição orçamentária fraca e postura fiscal nos estados brasileiros. BNDES. $25^{\circ}$ Prêmio BNDES de Economia.

20. Rigolon F, Giambiagi F (1999) A renegociação das dívidas e o regime fiscal dos Estados. In: Giambiagi. F.\& Moreira. M. M. (Orgs.). A economia brasileira nos anos 90 :(111-146). Rio de Janeiro: BNDES.

21. Pellegrini JA (2012) Dívida Estadual: Texto para Discussão $\mathrm{n}^{\circ} \quad 110 \quad \mathrm{da}$ Consultoria Legislativa do Senado Federal. De março de. Recovered from https://www12.senado.leg.br/publicacoes/estudos -legislativos/tipos-de-estudos/textos-paradiscussao/td-110-divida-estadual.

22. Lei $\mathrm{n}^{0} 7.614$, of July $14^{\text {th }}$, (1987) It authorizes, on an extraordinary basis, credit operations to the National Treasury's account and risk, and takes other measures. Recovered from http://www.planalto.gov.br/ccivil_03/LEIS/19801988/L7614.htm.

23. Lei $\mathrm{n}^{0}$ 9.496, of September $11^{\text {th }}$, (1997) it establishes criteria for the consolidation, assumption and refinancing, by the Union, of public securities debt and others that it specifies, under the responsibility of the States and the Federal District. Recovered from http://www.planalto.gov.br/ccivil_03/leis/L9496.h tm. 
24. Lei Complementar $\mathrm{n}^{0} 156$, of December $28^{\text {th }}$, (2016) It establishes the Aid Plan for States and the Federal District and measures to encourage fiscal rebalancing; and amends Complementary Law No. 148 of November 25 th 2014 , Law No. 9,496, of September 11 th 1997 , Provisional Measure No. 2,192-70, of August 24th, 2001 , Law No. 8,727, of 5 of November, 1993, and Complementary Law No. 101, of May 4, 2000. Recovered from http://www.planalto.gov.br/ccivil_03/leis/LCP/Lc p156.htm\#art8.

25. Lei Complementar $\mathrm{n}^{\mathrm{o}} 148$, of November $25^{\text {th }}$, (2014) It amends Complementary Law 101, of May 4, 2000, which establishes public finance rules aimed at responsibility in fiscal management provides for indexing criteria for debt refinancing contracts entered into between the Federal Government, States, the Federal District and Municipalities; and makes other arrangements. Recovered from http://www.planalto.gov.br/ccivil_03/leis/lcp/Lcp 148.htm.

26. Lei $\mathrm{n}^{\mathrm{o}} 8.727$, of November $5^{\text {th }}$, (1993) It establishes guidelines for the consolidation and rescheduling, by the Union, of internal debts of the direct and indirect administrations of the States, the Federal District and the Municipalities, and takes other measures. Recovered from http://www.planalto.gov.br/ccivil_03/LEIS/L8727 .htm.

27. Lei Complementar $n^{0} 101$, of May $4^{\text {th }},(2000)$ It establishes public finance rules aimed at responsibility in fiscal management and takes other measures. Recovered from http://www.planalto.gov.br/ccivil_03/leis/lcp/lcp1 01.htm.

28. Mora M (2002) Federalismo e Dívida Estadual no Brasil [Texto para discussão. $N^{\circ}$ 886]. Rio de Janeiro. RJ: IPEA.

29. Constituição da República Federativa do Brasil de (1988). Recovered on November 30th 2016 https://www.planalto.gov.br/ccivil_03/constituica o/ConstituicaoCompilado.html
30. Freire FS, Freire Filho R (2006 maio) Análise de endividamento dos estados brasileiros período de 2000 a 2004. Anais do Congresso Brasileiro de Custos. Belo Horizonte. MG. 13.

31. Resolução do Senado Federal $n^{0} 40$. de 20 de dezembro de (2001) It provides for global limits for the amount of consolidated public debt and public securities debt of states, the federal district and municipalities, in compliance with the provisions of article 52, VI AND IX, of the Federal Constitution. Recovered from https://legis.senado.leg.br/norma/562458.

32. Martins GA (2002) Estatística geral e aplicada. 2. ed. São Paulo: Atlas.

33. Silva IFBR, Sousa MCS (2002) Determinantes do endividamento dos estados brasileiros: uma análise de dados de painel [Texto para discussão. $\mathrm{N}^{\circ}$ 259]. Brasília. DF: Departamento de Economia. UnB.

34. Horta GTDL (2011 dezembro) Administração da Dívida Pública: um estudo para o caso brasileiro. Anais do Encontro Nacional de Economia. Foz do Iguaçu. PR. 39. Recovered from https://www.anpec.org.br/encontro/2011/inscrica o/arquivos/000fc16b3436224578e886e447722324776.pdf.

35. Campos's O (2008 novembro) Análise do endividamento dos estados brasileiros, período de 2005 e 2006. Anais do Congresso Brasileiro de Custos. Curitiba. PR. Brasil. 15.

36. Carvalho JRM, Oliveira GF, Santiago JS (2010) Dívida pública: um estudo de indicadores dos Estados Nordestinos. Revista Universo Contábil, 6(2):82-100. 